Kamila Szymańska

ORCID: 0000-0002-8777-2016

Muzeum Okręgowe w Lesznie

\title{
Ikonografia Jana Amosa Komeńskiego w zbiorach Muzeum Okręgowego w Lesznie
}

\author{
Iconography of John Amos Comenius \\ in the collections of the District Museum in Leszno
}

DOI: $10.34739 /$ szk.2021.08.15

\begin{abstract}
Streszczenie: W artykule przedstawiono kolekcję obiektów ikonograficznych ukazujących wizerunki Jana Amosa Komeńskiego: obrazy olejne, grafiki, medale i plakiety, pocztówki, numizmaty. Omówiono je $\mathrm{z}$ uwzględnieniem historycznego kontekstu ich powstania oraz sposobami pozyskania do zbiorów. Artykuł, mimo przeglądowego charakteru, ma na celu zwrócenie uwagi na podobne zbiory w innych polskich instytucjach.
\end{abstract}

Słowa kluczowe: Jan Amos Komeński, ikonografia, zbiory muzealne, Muzeum Okręgowe w Lesznie

Abstract: The article presents a collection of iconographic objects showing the images of John Amos Comenius: oil paintings, graphics, medals and plaques, postcards, and numismatic items. They are discussed taking into account the historical context of their creation and the methods of obtaining them for the collection. The article, despite its review character, aims to draw attention to similar collections in other Polish institutions.

Keywords: Jan Amos Comenius, iconography, museum collections, the District Museum in Leszno

W ostatnich latach czeska komeniologia sporo miejsca poświęciła zagadnieniu ikonografii portretowej Comeniusa, czego podsumowaniem jest bez wątpienia książka Markéty Pánkovej, napisana we współpracy z Aleną Matyášovą (Pánkova, Matyášova, 2017). Publikacja ta wraz z obszernym artykułem Blanki Jeřábkovej i Heleny Kovářovej (Jeřábková, Kovářova, 2018), będącym szczegółową analizą istniejących wizerunków graficznych i malarskich Jana Amosa Komeńskiego, stała się inspiracją do przyjrzenia się komeniologicznym zbiorom Muzeum Okręgowego w Lesznie pod kątem posiadanej ikonografii Nauczyciela Narodów. Okazją sprzyjającą wszelkiego rodzaju podsumowaniom był również obchodzony w 2020 r. jubileusz śmierci Komeńskiego i początku wojny trzydziestoletniej, tak bezpośrednio związanej 
z nim i braćmi czeskimi. Niniejsze opracowanie ma charakter omówienia kolekcji nie tylko z uwagi na jej zawartość, ale także zważywszy na proweniencję posiadanych obiektów i ich historyczne związki z Lesznem - obiekty te nie znalazły się w Lesznie i w muzeum przypadkowo. W takim kontekście fakt opisania zbioru nabiera sensu i może stać się przyczynkiem do badań nad reprezentatywnością wizerunków Komeńskiego w zbiorach polskich, proporcjami pomiędzy ich oryginalnością bądź wtórnością w stosunku do zbiorów czeskich, dla których wskazane na wstępie publikacje mogą być punktem odniesienia i porównania.

Poniżej przedstawiona ikonografia w zbiorach leszczyńskich odwołuje się wprost do wspomnianych czeskich wydawnictw, w których obok egzemplifikacji wizerunku Comeniusa w postaci malarstwa, grafiki, rzeźb, medalierstwa poważnie potraktowane zostały także formy użytkowe, jak pocztówki czy banknoty.

Pierwowzorem wszystkich wizerunków Komeńskiego są grafiki powstałe w Anglii i Holandii w XVII w. Najstarszy znany portret Comeniusa to dzieło Georga Glovera, rytownika czynnego w latach 1625-1652, wykonane na podstawie rysunku przypisywanego Václavovi Hollarowi (1607-1677), zamieszczone w angielskiej edycji Prodromus pansophiae z 1642 r. Kolejne angielskie wizerunki opublikowano w 1652 (miedzioryt według rysunku Hollara) i w 1656 r., gdy jako frontispis do londyńskiego wydania Latinae linquae janua reserata z 1656 r. wykorzystano pracę Thomasa Grossa (rytownik czynny w latach 1644-1682). Pierwowzór holenderski, ryty przez Davida Loggana (1634-1692), na podstawie obrazu Crispina van de Passe młodszego (1593-1670), stał się jednym z najczęściej naśladowanych portretów Comeniusa przez pokolenia kolejnych artystów, a traktowany jako inspiracja nadal jest podstawą dla nowych prac malarskich i graficznych. Przedstawia on Komeńskiego jako starca siedzącego przy stole, w otoczeniu licznych instrumentów naukowych oraz alegorii nauki i poznania. Ten bogaty program ikonograficzny, zamieszczony jako frontispis Opera didactica omnia w amsterdamskiej edycji z 1657 r., oddaje w pełni życiowe posłannictwo Komeńskiego (Pánková, Matyášová, 2017: 33-38).

Najważniejszym portretem Komeńskiego w zbiorach Muzeum Okręgowego w Lesznie jest wizerunek namalowany około 1855 r. przez Ferdynanda Gregora (ur. 1811), malarza i litografa, wykształconego w Akademii Berlińskiej, w latach 1852-1869 nauczyciela rysunku w gimnazjum w Lesz- 
nie ${ }^{1}$. Wzorowany na graficznym przedstawieniu Crispina van de Passe, ukazuje Komeńskiego w popiersiu, siedzącego za stołem podczas pisania. Powstanie tego obrazu, jak i pozostałych wizerunków rektorów leszczyńskiego gimnazjum, ma swoją genezę w procesie odnowy szkoły i rozwoju życia kulturalnego w Lesznie.

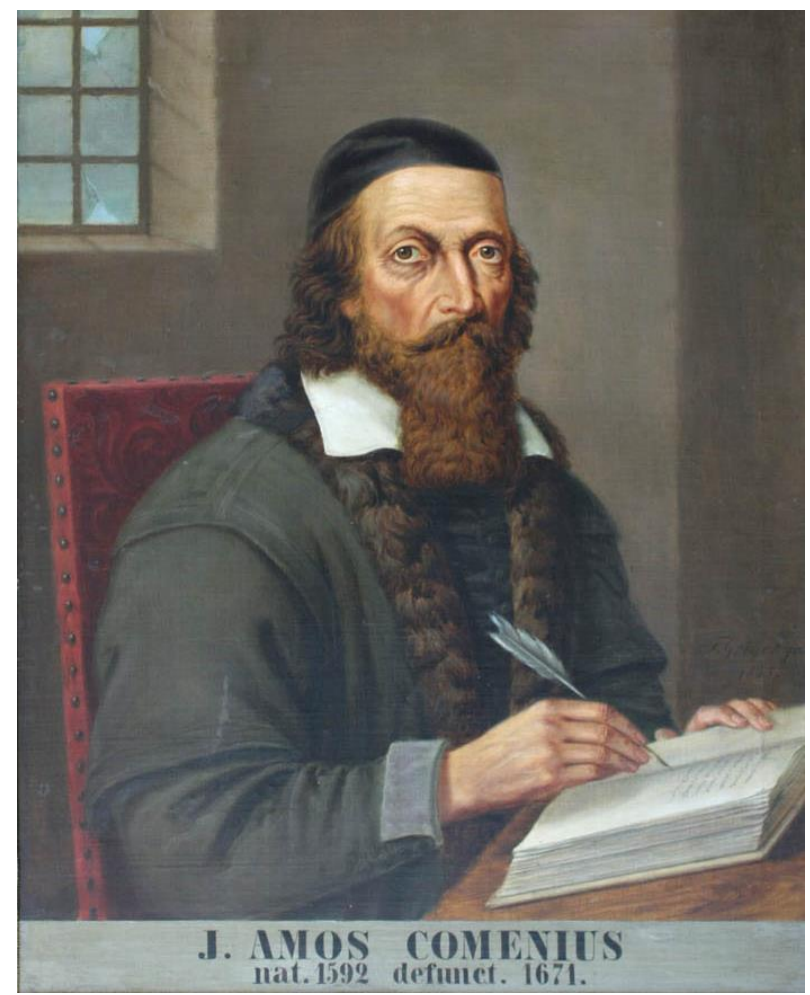

Ilustracja 1 - Portret Komeńskiego z galerii portretów leszczyńskiego gimnazjum autorstwa Ferdynanda Gregora, namalowany z okazji 300. rocznicy założenia szkoły. Muzeum Okręgowe w Lesznie, nr inw. MLH 1493. Fot. Tomasz Sikorski.

Jednym z przejawów tego ożywienia była wzmożona działalność środowisk intelektualnych, skupionych wokół gimnazjum, drukarni Ernsta Wilhelma Günthera oraz księcia Antoniego Sułkowskiego - ordynata rydzyńskiego, jaką obserwujemy w Lesznie od lat 20.-30. XIX w. Około 1820 r. zrodził się pomysł stworzenia galerii rektorów szkoły. Jako pierwszy uwieczniony został ówczesny rektor, Bogusław Dawid Cassius (1746-1828), sportretowany przez mistrza leszczyńskiego cechu malarzy i nauczyciela rysunku w miej-

\footnotetext{
${ }^{1}$ MLS 1493, 92 x 72 cm; w zbiorach od 2010; wcześniej jako depozyt I Liceum Ogólnokształcącego.
} 
scowym gimnazjum w latach 1822-1852, Johanna Gottfrieda Arndta (17721858). Spośród dziewięciu portretów, jakie powstały do 1905 r., obraz przedstawiający Komeńskiego osadzony jest ściśle w atmosferze kulturalnego ożywienia i przygotowań do obchodzonego uroczyście jubileuszu gimnazjum. Kolejne podobizny dawnych, wybitnych rektorów: Daniela Ernesta Jabłońskiego i Dawida Cassiusa powstały w latach 1850-1855, dalsze sukcesywnie za życia aktualnych rektorów szkoły (Sanden, 1905: 13, 26-27, 40-42)². Wizerunek Comeniusa stanowił istotny element jubileuszowych uroczystości, bo jego reprodukcja pojawiła się na okolicznościowych wydawnictwach, jakie z tej okazji powstały. Obraz ten odgrywał podobną rolę także w 1905 r., gdy obchodzono 350 rocznicę powstania szkoły (Szymańska, 2012, s. 60-63). Wówczas, dla uczczenia jubileuszu, wydano m.in. monografię szkoły pióra Sandena ze zreprodukowanymi wizerunkami rektorów oraz pocztówkę, która - w ozdobnej kompozycji - wyeksponowała je, dając portretowi Komeńskiego uprzywilejowane, centralne miejsce ${ }^{3}$.

Portret pędzla Gregora ma interesującą historię, a badaczom wizerunków Komeńskiego sprawił problemy z datowaniem (Jeřábková, Kovářová, 2018: 169-170). Czeski uczony Jiří Václav Klíma (1874-1948) uznał, że galeria portretów rektorów malowana była za życia kolejnych osób kierujących leszczyńskim gimnazjum, co doprowadziło go do błędnego założenia, jakoby ten portret był pierwowzorem dla późniejszych wizerunków Comeniusa. Obraz ten interesujący jest $\mathrm{z}$ innego jeszcze powodu. Inskrypcja zawarta u dołu portretu zawiera błąd w dacie roku śmierci sportretowanego: zamiast 1670 znalazła się data 1671. Być może nie jest to dzieło przypadku i błąd artysty, a wręcz przeciwnie, wynik dociekań i poszukiwań źródłowych Gregora. Taka sama data śmierci widnieje bowiem w podpisie wizerunku graficznego zamieszczonego w berlińskiej edycji z 1782 r. Labiryntu świata i raju serca (Panková, Matyášová, 2017: 46) i kolejnej, praskiej z 1786 r., być może znanych artyście.

Obraz szybko wszedł do publicznego biegu. W 1892 r. sfotografował go leszczyński fotograf Ottomar Anschütz (1846-1907), a reprodukcje tego zdjęcia pojawiły się w czeskich wydawnictwach oraz w publikacjach wydawanych w Lesznie dotyczących Komeńskiego, braci czeskich i miasta w ogóle.

Wizerunek ten wykazuje znaczne podobieństwo do obrazu znajdującego się w Herrnhut (Jeřábková, Kovářová, 2018: s. 170), co może być uzasad-

\footnotetext{
2 W zbiorach Muzeum znajdują się portrety rektorów: Daniela Ernesta Jabłońskiego, Dawida Cassiusa i Bogusława Dawida Cassiusa. Losy pozostałych portretów rektorów: Johanna Christopha von Stöphasiusa, Georga Schölera, Adalberta Zieglera, Friedricha Hermanna Eckhardta, Karla Kuntzego i ordynata Antoniego Sułkowskiego pozostają nieznane.

${ }^{3}$ MLH 4867; 13,7 x 8,9 cm. Zakup, 2018.
} 
nione związkami duchownych z Herrnhut odwiedzających Leszno w pierwszej połowie XIX w. (Szymańska, 2019: 104), którzy mogli ów portret widzieć. Równie uprawnione jest jednak powstanie herrnhuckiego obrazu na podstawie XVII-wiecznych grafik i bez jakiegokolwiek związku z Lesznem.

Kolejne olejne wizerunki Komeńskiego, znajdujące się w zbiorach muzeum, są czeskiej proweniencji. Datowane na 2. połowę XIX w., należą do powstających wówczas dość powszechnie obrazów przedstawiających Nauczyciela Narodów w charakterystycznych pozach. Anonimowi twórcy tych dzieł wzorowali się na powstałych uprzednio pracach i trudno wskazać bezpośrednie źródła inspiracji.

Wizerunek, na którym sportretowany trzyma w dłoniach opasły egzemplarz Orbis sensualium pictus ${ }^{4}$ powtarza ujęcie znane z obrazu morawskiego artysty Josefa Zelený'ego (1824-1886), opublikowane w wydaniu Labiryntu świata i raju serca z 1871 r. (Jeřábková, Kovářová, 2018: 161). Drugi portret ${ }^{5}$ wzorowany był zapewne na pracy Václava Brožika (1851-1901), bo na leszczyńskim płótnie odmienny od niej jest jedynie sposób trzymania księgi i szczegóły ubioru (Pánková, Matyášová, 2017: 159).

Zbiory graficzne reprezentują dwa przedstawienia stanowiące ilustrację dzieł i treści związanych z Komeńskim. Starszy z obiektów jest jednym z kilku wariantów portretu występującego w XVIII-wiecznych edycjach dzieł Comeniusa. W naszym przypadku to wizerunek teologa w podeszłym wieku, ujęty z prawej strony, ukazany $\mathrm{w} 3 / 4$ postaci z otwartą księgą $\mathrm{w}$ rękach, opartą o blat. Poniżej znajduje się postument z inskrypcją o treści: Jan Amos Komensky / životè svem / Senior gednoty českè bratrskè / w lessné polskem / naroz. $A^{o} .1592$ w Panu ůsnůl $A^{o}$. 1671. Kompozycja znajduje się w praskim wydaniu Praxis pietatis z 1786 r. ${ }^{6}$ Jest to dzieło anonimowego grafika, znane też z berlińskiego wydania z 1782 r. (Jeřábková, Kovářová, 2018: s. 145-146). Edycja ta - oprócz inskrypcji - ma inny jeszcze związek z Lesznem. Oprócz przedmowy Komeńskiego z 1661 r. zawiera także drugą przedmowę z wydania niemieckiego, wspomnianego powyżej, której autorem był Johann Gottlieb Elsner (1717-1782) - duchowny czeskobraterski, delegowany z Leszna, gdzie został w 1747 r. wyświęcony na ministra, do Berlina, by pełnić posługę wśród czeskich emigrantów (Strobel, 2015: 183-198).

\footnotetext{
${ }^{4} \mathrm{Nr}$ inw. MLS 1482; 51,1 x 38,7 cm. Zakup, 2008.

${ }^{5} \mathrm{Nr}$ inw. MLS 1481; 69,8 x 49,6 cm. Zakup, 2008.

${ }^{6} \mathrm{Nr}$ inw. S. 193. Dar, 2018.
} 


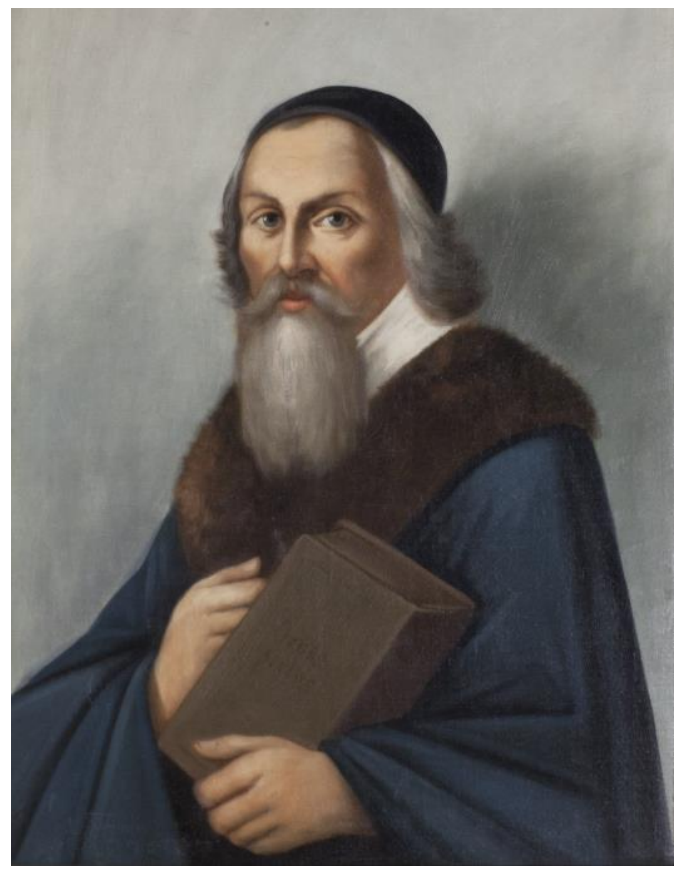

Ilustracja 2 - Portret Komeńskiego, 2 poł. XIX w. Muzeum Okręgowe w Lesznie, nr inw. MLS 1482. Fot. Tomasz Sikorski.

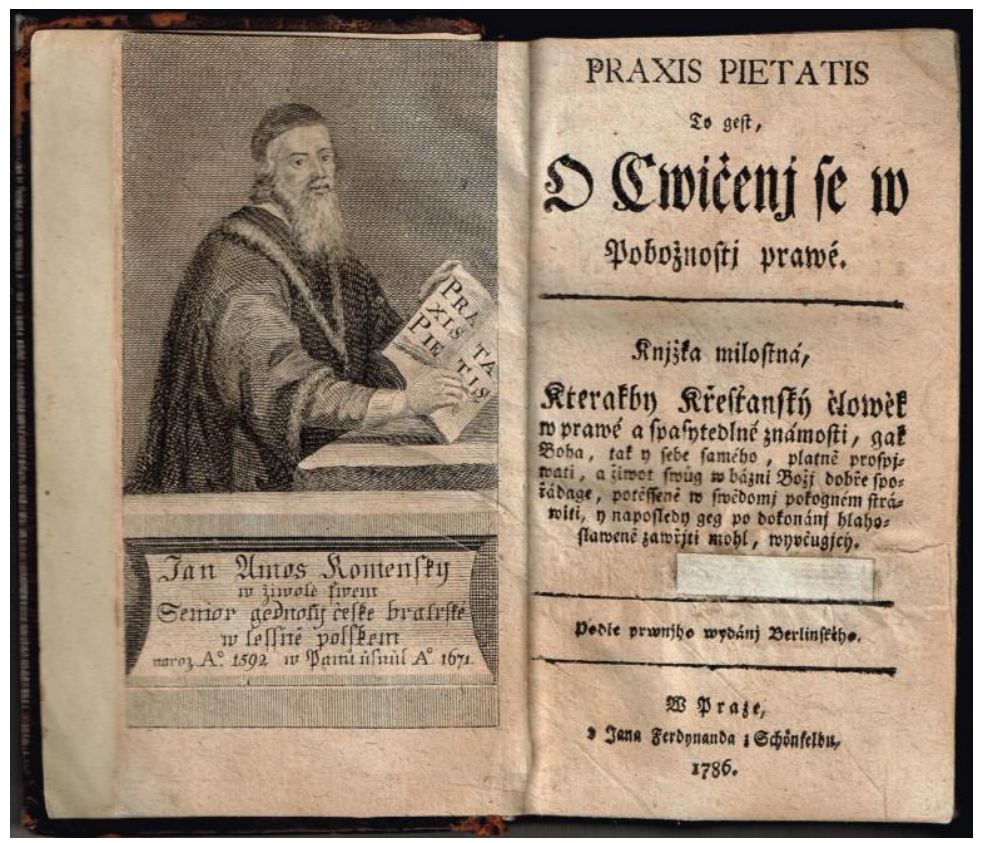

Ilustracja 3 - Portret Komeńskiego w praskiej edycji Praxis pietatis z 1786 r. Muzeum Okręgowe w Lesznie, nr inw. S. 193. For. Kamila Szymańska. 
Drugi graficzny portret Comeniusa pochodzi z „Przyjaciela Ludu”, czasopisma wydawanego w Lesznie w latach 1834-1848, nakładem drukarza, księgarza i wydawcy Ernsta Wilhelma Günthera ${ }^{7}$. Wzorowany był prawdopodobnie na pracy praskiego miedziorytnika i wydawcy Jana Balzera (17361799) z 1772 r., rytej na podstawie rysunku Jana Kleinharda (Jeřábková Kovářová, 2018: 147). Portret, przeniesiony na karty periodyku za pomocą litografii, posłużył jako ilustracja artykułu pióra Józefa Łukaszewicza pt. Jan Amos Komeński, niegdyś rektor szkół w Lesznie, zamieszczonego w 7 numerze rocznika z $1834 \mathrm{r}$. Komeński przedstawiony został na nim $\mathrm{w} 3 / 4$ postaci, w popiersiu. W pierwowzorze wizerunek ujęty był w owalną ramę, pod którą umieszczono kartusz z napisem identyfikującym uwiecznioną postać.

W zbiorach ikonograficznych muzeum znajdują się także pocztówki z wyobrażeniem Comeniusa. Jedna z nich, nieznanego wydawcy z początku $\mathrm{XX}$ w., uzupełnia galerię portretów pedagoga ${ }^{8}$. Przedstawia go w podeszłym już wieku, z posiwiałą brodą, z rękoma opartymi na blacie stołu, z zatroskanym i smutnym wyrazem twarzy. Oryginalny i zaskakujący jest strój, w jaki odziany jest Komeński - to szata kardynalska, która stała się powodem dyskusji w gronie badaczy. Oryginalny obraz, eksponowany od 1899 r. w Rudolfinum w Pradze, funkcjonował do lat 60. XX w. jako portret kardynała. Jego autorem jest Jaroslav Čermák (1830-1878), który w czasie powstania dzieła - około 1850 r. - był bardzo młodym człowiekiem, co uznano za wytłumaczenie „przyodziania” bohatera obrazu w niewłaściwy strój. Čermák namalował Komeńskiego będąc w Holandii, wzorując się na pracach XVII-wiecznych artystów (Pánková, Matyášová: 154-156).

Kilka kolejnych pocztówek ${ }^{9}$ odwzorowuje pomnik Komeńskiego w Lesznie. Obiekty różnią się od siebie jedynie detalami: sposobem ujęcia, ukazaniem otoczenia pomnika, jakim najczęściej jest gmach gimnazjum lub kościoła, przed którym monument został postawiony. Część z nich wydana została jako pamiątki obchodzonych w mieście jubileuszy, co podkreślają stosowne napisy. Pomnik pojawia się także na kilku pocztówkach wielotematycznych ukazujących najważniejsze leszczyńskie lokalizacje i miejsca godne uwagi. Inicjatorami ukazania się tych pocztówek byli miejscowi wydawcy. Szczególną aktywność w tej mierze przejawiało wydawnictwo Friedrich Ebbecke's Verlag, należące do Oskara Eulitza oraz Samusa Breslauera.

\footnotetext{
${ }^{7} \mathrm{Nr}$ inw. B. 1. Zakup, 1950.

${ }^{8} \mathrm{Nr}$ inw. MLH 4788; 13,9 x $9 \mathrm{~cm}$. Zakup, 2010.

${ }^{9}$ Nr inw.: MLH 1334, MLH 1335, MLH 1337, MLH 2152, MLH 4867, MLH 4790, MLH 4791.
} 


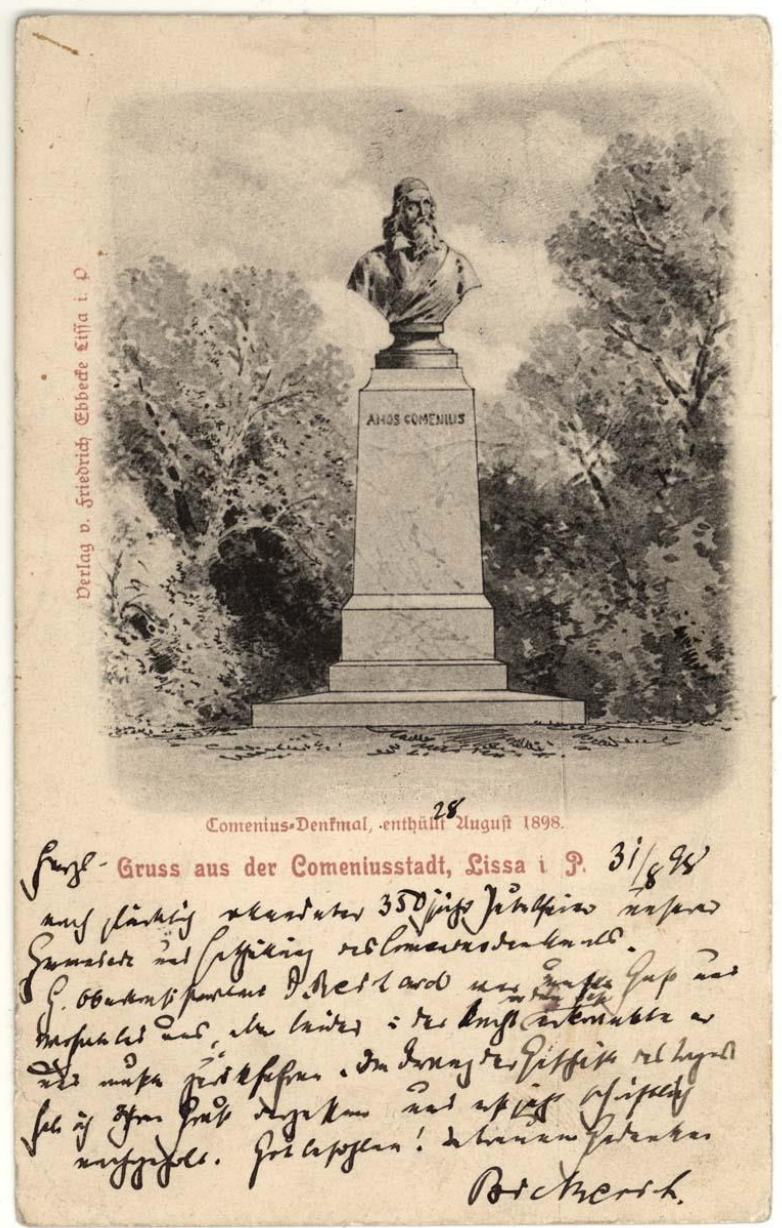

Ilustracja 4 - Okolicznościowa karta pocztowa z wizerunkiem pomnika Komeńskiego i korespondencją W. Bickericha; Leszno, Friedrich Ebbecke’s Verlag, 1898. Muzeum Okręgowe w Lesznie, nr inw. MLH 1335. Fot. Tomasz Sikorski.

Powstanie pomnika, tak chętnie uwiecznianego w rozmaitych wydawnictwach i drukach akcydensowych, ma interesującą historię. Zainteresowanie Komeńskim i braćmi czeskimi - jak już wspomniano - zbiegło się w Lesznie z odrodzeniem słowiańskim w Europie Środkowej i paradoksalnie było tu udziałem nie tylko środowisk polskich, w tym głównie Józefa Łukaszewicza, ale zwłaszcza niemieckich kadr gimnazjum i duchownych parafii św. Jana, doceniających siłę tradycji i wyjątkową historię tych instytucji. Osobą, która w sposób szczególny podjęła tematykę czeskobraterską i komeniologiczną, był przybyły do Leszna w 1892 r. wówczas młody duchowny Wilhelm Bickerich (1867-1934). Ujawniona bardzo szybko pasja historyczna owocowała przez całe życie pastora długą listą publikacji i opracowań źródłowych opisu- 
jących dzieje Jednoty, Komeńskiego oraz protestantyzmu w Wielkopolsce. Odsłonięty pomnik Comeniusa był zasługą duchownego, który 4 marca 1898 r., z okazji jubileuszu 350-lecia przybycia Komeńskiego i braci czeskich do Leszna, ogłosił konkurs na projekt monumentu i zorganizował zbiórkę funduszy na ten cel w Europie Zachodniej, docierając z przesłaniem do wspólnot ewangelicko-reformowanych i środowisk naukowych (Błaszkowski, 2012: 53-71). W efekcie zakrojonej na szeroką skalę działalności pomnik autorstwa berlinskiego artysty Alfreda Reichela (1856-1928) został odsłonięty w nadzwyczaj krótkim czasie, bo już 28 sierpnia 1898 r. Podczas uroczystości Bickerich wygłosił okolicznościową mowę, która wydrukowana w Berlinie pt. Die Geistesrichtung des Comenius. Weiherede bei der Entheilung des Comenius-Denkmals zu Lissa i.P. zawierała dodatkowo informacje o Comenius-Gesellschaft, powołanym 10 października 1891 r. z zachętą do finansowego wsparcia jego działalności oraz dokończenia przedsięwzięcia, jakim była budowa pomnika Komeńskiego. Z tej samej okazji nauczyciel leszczyńskiego gimnazjum Franz Nesemann wydał broszurę Ein Denkmal des Johann Amos Comenius in Lissa zum dreihundertfünfzig... Odsłonięty pomnik nie bez powodu stał się istotnym motywem ilustracyjnym publikacji dotyczących Leszna, parafii, szkoły oraz głównym tematem m.in. pocztówek.

Leszczyński monument znalazł odwzorowanie także w małej formie graficznej, jaką jest exlibris Wilhelma Bickericha ${ }^{10}$. Sam exlibris tworzy rozbudowana kompozycja o bogatym programie ikonograficznym, czytelnym i jasnym w kontekście biografii, postawy zawodowej i naukowej właściciela, gdzie w otoczeniu symboli Trójcy świętej, Wieczerzy Pańskiej, książek, płonącej świecy oraz emblematów będących powtórzeniem polichromii znajdującej się na stropie kościoła św. Jana, przedstawiających: palmę na pustyni, arkę na morzu i rękę wyłaniającą się z nieba podlewającą z konewki ziemię, znajduje się także popiersie Komeńskiego wieńczące cokół. Exlibris łączy elementy posługi pastorskiej Bickericha z miejscem jej pełnienia, podkreśla korzenie wspólnoty kościelnej odwołujące się do braci czeskich i ich duchowego przywódcy, Jana Amosa Komeńskiego, a równocześnie oddają kierunki naukowych pasji duchownego.

Z Alfredem Reichelem - twórcą monumentu - wiąże się inny jeszcze wizerunek Komeńskiego - gipsowa plakieta z popiersiem pedagoga, pochodząca z wyposażenia kościoła św. Jana ${ }^{11}$. Gipsowy odlew o średnicy blisko $54 \mathrm{~cm}$, przedstawia duchownego w popiersiu, zwróconego 3/4 postaci do wi-

\footnotetext{
$10 \mathrm{Nr}$ inw. S. 104; 13,9 x 9,3 cm, w: J.A. Komeński, Erste Liebe, Frankfurt u. Leipzig 1743. Zakup, 1961.

$11 \mathrm{Nr}$ inw. MLH 220; średnica 53,5 cm. Przekaz, 1970.
} 
dza. Wokół, na szerokim pasie okalającym wizerunek, znajduje się napis „+ 1592 + AMOS COMENIUS + 1670+", a na popiersiu sygnatura o treści: „A. Reichel feb.1894”. Plakieta powstała w 1894 r. jako jeden z licznych odlewów gipsowych medalionu z brązu, wykonanego w 1892 r., i rozprowadzana była m.in. w szkołach.

Do zbiorów muzeum trafił inny interesujący obiekt - gipsowe popiersie Komeńskiego wykonane w berlińskim zakładzie braci Claudia i Aurelia Michelich. Firma założona w 1824 r. znana była z szerokiej oferty gipsowych odlewów antycznych dzieł muzealnych oraz popiersi osobistości historycznych: władców, polityków, uczonych i pisarzy. W bogatej ofercie Michelich znalazło się również popiersie Comeniusa. Datowany na około $1860 \mathrm{r}$. biust należał do Liceum Pedagogicznego, szkoły działającej w latach 1937-1969 (Jędraś, 2014: 19) ${ }^{12}$. Po zlikwidowaniu szkoły przekazany został do zbiorów muzeum. Popiersie nieprzypadkowo znajdowało się w tej placówce edukacyjnej. Szkoła kontynuowała tradycje Królewskiego Katolickiego Seminarium dla Nauczycielek z czasów pruskich, które po odzyskaniu niepodległości funkcjonowało jako Żeńskie Seminarium Nauczycielskie, w 1937 r. przemianowane na Liceum Pedagogiczne. $W$ nowych realiach powojennych szkoła działała nadal, a 14 września 1947 r., podczas uroczystości 400-lecia lokacji miasta, nadano jej imię Jana Amosa Komeńskiego. Jednym z przejawów nawiązywania do patrona był działający w placówce teatr szkolny, skupiający 18 uczniów i odwołujący się do zasad głoszonych przez Komeńskiego. Scena ta wsławiła się zwłaszcza polską prapremierą „Gry o Diogenesie” w tłumaczeniu Zdzisława Kunstmana i reżyserii Zdzisława Smoluchowskiego, która miała miejsce w grudniu 1963 r. Sztuka cieszyła się powodzeniem, bo wystawiono ją ośmiokrotnie, w tym m.in. w 1964 r. na Ogólnopolskim Festiwalu Teatrów Amatorskich w Łodzi (Smoluchowski, 1977: 173-195; 184-187).

W 2009 r. zbiory muzeum powiększyły się o patynowane gipsowe popiersie Comeniusa ${ }^{13}$, będące kopią znajdującego się w Muzeum Komeńskiego w Przerowie na Morawach biustu autorstwa rzeźbiarza i medaliera Josefa Bajáka (1906-1980) z 1948 r.

$12 \mathrm{Nr}$ inw. MLH 1829; 70,5 x $51 \mathrm{~cm}$. Przekaz, 1970.

$13 \mathrm{Nr}$ inw. MLPHa 2291; 38 x 26 cm. Dar, 2009. 


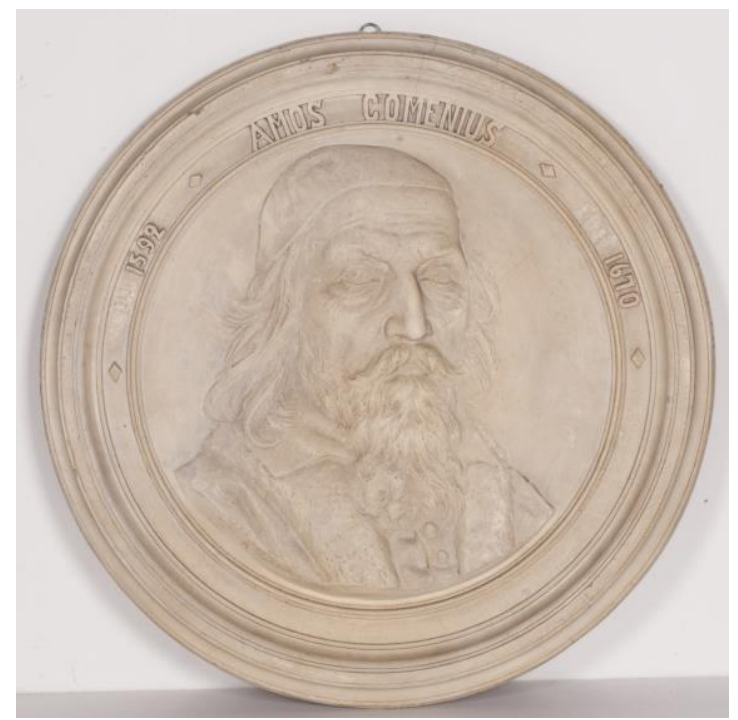

Ilustracja 5 - Plakieta autorstwa Alfreda Reichela z wyposażenia kościoła św. Jana w Lesznie; 1894. Muzeum Okręgowe w Lesznie, nr inw. MLH 220. Fot. Tomasz Sikorski.

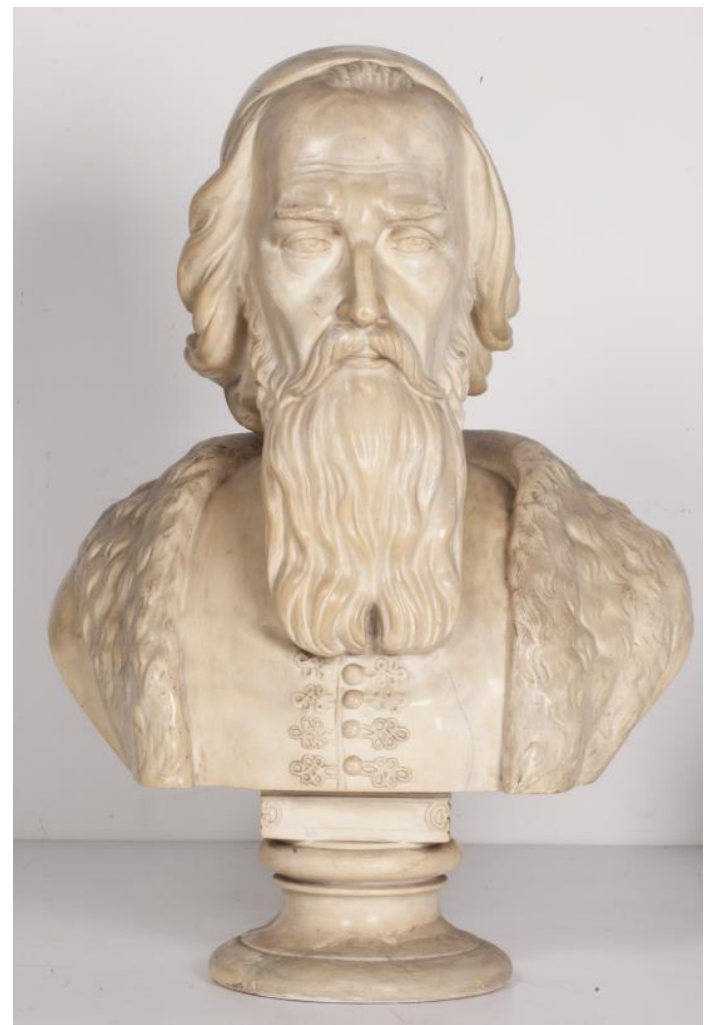

Ilustracja 6 - Popiersie autorstwa braci Micheli ze zbiorów Liceum Pedagogicznego w Lesznie; ok. 1860. Muzeum Okręgowe w Lesznie, nr inw. MLH 1829. Fot. Tomasz Sikorski. 
Spośród form medalierskich najstarsza w kolekcji jest XIX-wieczna plakieta nieustalonego autorstwa, odlana $\mathrm{z}$ żeliwa na kształt nieregularnego okręgu o średnicy $20,5 \mathrm{~cm}$. Przedstawia Komeńskiego ujętego z prawego profilu w dojrzałym wieku, z długą brodą, ponad którym znajduje się napis: „IOH. AMOS COMENIUS. PRAXIS PIETATIS” 14 .

Pozostałe medale mają charakter okolicznościowy, a ich powstanie wiąże się z kolejnymi jubileuszami obchodzonymi z okazji rozmaitych rocznic dotyczących życia Komeńskiego. Najwcześniejszym takim obiektem w zbiorach jest medal o średnicy $7,1 \mathrm{~cm}$, odlany $\mathrm{w}$ brązie $\mathrm{z}$ okazji 300 . rocznicy śmierci Komeńskiego ${ }^{15}$. Autorem medalu, przekazanego w 1970 r. do zbiorów przez Ambasadora Czechosłowacji Františka Penca, jest Karel Vašut (1929-2005). Inskrypcje znajdujące się zarówno na awersie ("SVĚTOVĚ KULTURNÍ VYROVÍ”), jak i rewersie („MDCLXX-MCMLXX / QVID / MELIVS POSSVMVS / FACERE QVAM PACEM / QVAERERE ? / Joh. A. Comenius"), wskazują na świętowaną rocznicę i okazję stworzenia dzieła (Pánková, Matyášová, 2017: 203).

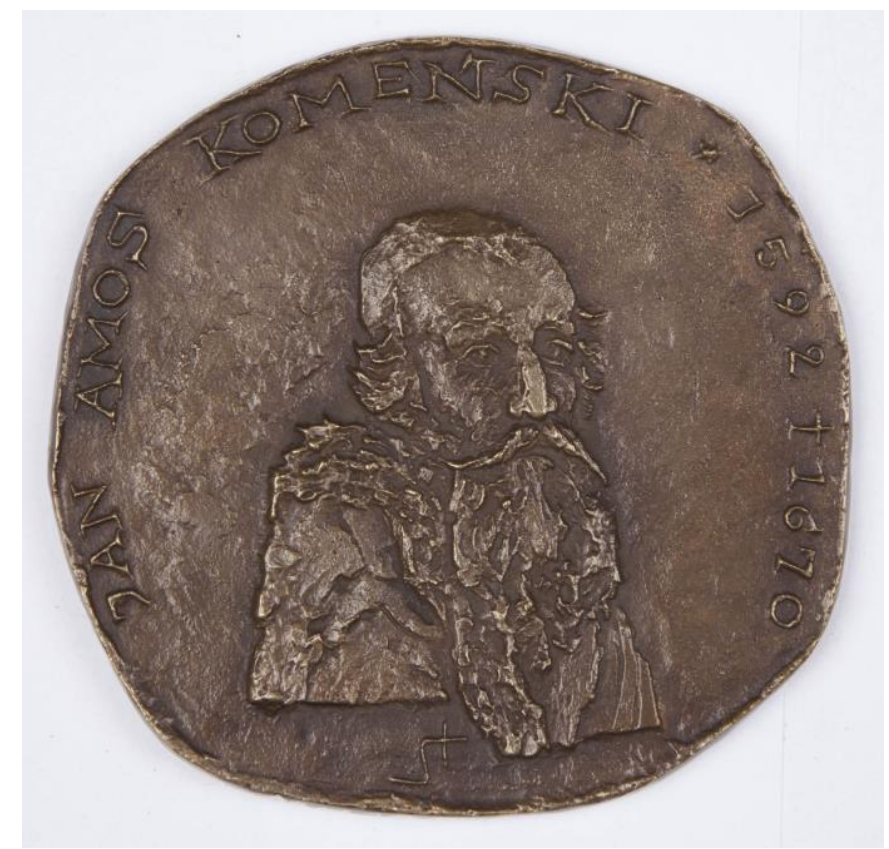

Ilustracja 7 - Medal okolicznościowy odlany dla uczczenia 300. Rocznicy śmierci Komeńskiego, autorstwa Józefa Stasińskiego. Muzeum Okręgowe w Lesznie, nr inw. MLH 1961.

Fot. Tomasz Sikorski.

14 Nr inw. MLH 3493; średnica 20,5 cm. Zakup, 1984.

$15 \mathrm{Nr}$ inw. MLH 1963; średnica 7,1 cm. Przekaz, 1970. 
Z tego samego powodu pracę wykonał poznański artysta Józef Stasiński (1927-2019) ${ }^{16}$. Jego medal odlany z brązu powstał na zlecenie Wielkopolskiego Towarzystwa Kulturalnego i leszczyńskiego muzeum, co upamiętnia inskrypcja na rewersie przedstawiająca portal muzeum. Na awersie podano okazję, którą uczczono medalem: „PAMIĘCI TWÓRCY NOWOŻYTNEJ PEDAGOGIKI W TRZECHSETNĄ ROCZNICĘ ŚMIERCI". Kolejne w zbiorze medale, autorstwa Zbigniewa Łukowiaka (1935-2007), powstały z inicjatywy Leszczyńskiego Towarzystwa Kulturalnego. Pierwszy odlany został w 1978 r. z okazji 350-lecia osiedlenia się Komeńskiego i braci czeskich w Lesznie17, ukazuje Komeńskiego zwróconego 3/4 postaci z prawego profilu, trzymającego w dłoniach książkę. Na rewersie przedstawiono fragment panoramy miasta, wzorowanej na grafice z $1775 \mathrm{r}$.

W 1992 r. wykonany został medal dla uczczenia urodzin Comeniusa i nawiązuje do motywu znanego z wizerunku autorstwa Crispina van de Passe. Medalier wyeksponował szczególne znaczenie jego dzieła pedagogicznego poprzez inskrypcję z tytułem Didactica opera omnia na awersie, a rolę Leszna poprzez tekst o treści: „NADE / WSZYSTKO / UPODOBAŁ / SOBIE / LESZNO"18. Uroczystości 400-lecia urodzin Komeńskiego upamiętnia inny jeszcze medal, ofiarowany do zbiorów w 2010 r. przez Narodowe Pedagogiczne Muzeum i Bibliotekę J.A. Komeńskiego w Pradze - inicjatora dzieła19. Obiekt ten ma szczególną historię, bo jego autor - prof. dr Jan Uher (1891-1942) - pedagog i propagator idei Komeńskiego, więziony podczas II wojny światowej w obozie w Diez an der Lahn, wyrzeźbił w lipowym drewnie plakietę z popiersiem Comeniusa. Przetrwała ona wojnę i w 1992 r. stała się podstawą do odlania medalu, który poprzez inskrypcje opowiada o okolicznościach jego powstania. Na awersie: „400 / J.A. Comenius / 1592-1670” // PEDAGOGICKÉ MUZEUM J.A. KOMENSKÉHO V PRAZE” i na rewersie: „PORTRET J.A. KOMENSKÉHO DO DŘEVA VYŘEZAL / prof. JAN UHER VE VEZNICI DIEZ AN DER LAHN / POPRAVEN BYL 27.10.1942. V PLÖTZENSEE" (Pánková, Matyášová, 2017: 76-77).

Ostatni obiekt to plakieta z lanego brązu autorstwa Igora Kitzbergera (ur. 1963) ${ }^{20}$. Praca tego czołowego czeskiego artysty-rzeźbiarza specjalizującego się w tworzeniu metalowych rzeźb figuralnych, wyróżnia się na tle pozostałych obiektów stylistyczną oryginalnością. Specyfiką twórczości Kitzbergera jest niezwykła ekspresja i dynamizm przedstawień. Wykorzysta-

\footnotetext{
$16 \mathrm{Nr}$ inw. MLH 1961; średnica 11,5 cm. Przekaz, 1971.

$17 \mathrm{Nr}$ inw. MLH 2358; 9,7 x 9,7 cm. Zakup, 1978.

$18 \mathrm{Nr}$ inw. MLH 4116; 8,4 x 9,2 cm. Zakup, 1992.

${ }^{19} \mathrm{Nr}$ inw. MLH 4797; 7,5 x 5,3 cm. Dar, 2010.

$20 \mathrm{Nr}$ inw. MLH 4806; średnica 7,3 cm. Zakup, 2011.
} 
ny do odlania plakiety wzór wizerunku Komeńskiego posłużył za podstawę dla medalu, jakim Państwowe Pedagogiczne Muzeum i Biblioteka J.A. Komeńskiego w Pradze honoruje osoby zasłużone dla propagowania dzieła i osoby Comeniusa. Warto zwrócić uwagę, że Kitzberger niejeden raz zaprzągł swój talent i wyobraźnię artystyczną do stworzenia wizerunku czeskiego pedagoga. Jest on bowiem autorem pełnopostaciowych pomników i statuetek Komeńskiego znajdujących się m.in. w Uherskim Brodzie, Přerovie, Týne nad Beczawą, Poczdamie.

Wizerunek Komeńskiego znajdował się także na monetach i banknotach emitowanych począwszy od 1892 r. (Panková, Matyášová, 2017: 117-121). W leszczyńskich zbiorach znajduje się banknot o nominale 20 koron z 1988 r. ${ }^{21}$ Pieniądz autorstwa Albína Brunovského, Miloša Ondračka i Václava Fajta znajdował się w obiegu w latach 1988-1993. Na awersie przedstawiony został $\mathrm{w}$ popiersiu Komeński z rozświetlonym promieniami słońca drzewem $w$ tle, na rewersie - w centrum kompozycji znajduje się owocujące i kwitnące obficie drzewo wyrastające $\mathrm{z}$ otwartej księgi. Z prawej strony kobieta i mężczyzna z ożywieniem komentują tekst z otwartej księgi. Całość dopełniają m.in. przedstawienia modelu atomu, tęczy i kwiatów dzikiej róży.

Zgromadzone wizerunki Komeńskiego w zbiorach Muzeum Okręgowego w Lesznie, choć nieliczne, tworzą zróżnicowany pod względem formy zbiór. Jego wartość pozaartystyczną wyznacza związek uwiecznionego na obiektach uczonego i teologa z miastem i jego instytucjami na różnych etapach dziejów. Część z nich dokumentuje owe relacje w sposób bezpośredni, bo powstały w okolicznościach szczególnych. Zdecydowanie największe znaczenie ma XIX-wieczny portret z galerii rektorów leszczyńskiego gimnazjum oraz najstarsze formy rzeźbiarskie. Ze zgoła innego, nieartystycznego powo$\mathrm{du}$, na uwagę zasługują także pocztówki powstałe z okazji obchodzonych w Lesznie jubileuszy. Podkreślają trwanie, pamięć i kultywowanie tradycji w mieście, co ma zdecydowanie większe znaczenie niż popularna forma tych obiektów i ich przeciętne walory. Dzięki takiej właśnie postaci - wysokonakładowej i niedrogiej - miały one szansę promować osobę i dzieło Comeniusa wśród mieszkańców i przyjezdnych oraz budować pozytywny wizerunek miasta, szczycącego się mianem „miastem szkół”. Kilka obiektów trafiło do zbiorów w wyniku współpracy z czeskimi instytucjami. Brak natomiast poza medalierstwem i rzeźbą - jakichkolwiek współczesnych form malarskich lub graficznych, co ewidentnie podkreśla niezmienność ustalonego kanonu wyobrażeń Komeńskiego, ukształtowanych w XVII w. i powielanych

${ }^{21} \mathrm{Nr}$ inw. MLH 4036; 6,7 x 13,7 cm; seria i numer: E15 738352. Dar, 1990. 
- z niewielkimi odstępstwami - w stuleciach następnych. To sytuacja zupełnie odmienna od sztuki czeskiej oraz designu, gdzie postać Komeńskiego inspiruje i kreuje nowe wyobrażenia Morawianina (Panková, Matyášová: np. 98, 100, 105-108, 124; Comenius, rozdział IX).

\section{Bibliografia}

Błaszkowski Marcin, Pomnik Jana Amosa Komeńskiego w Lesznie - kontekst historyczny powstania oraz dzieje, „Rocznik Leszczyński” 2012, nr 12, s. 53-71.

Jeřábková Blanka, Kovářová Helena, Comenius - Meisterhaft ins Bild gesetzt (Comenius-Bildnisse und Ihre Wirkungsgeschichte), „Studia Comeniana et Historia” 2018, XLVIII, 99-100, s. 121-177.

Pánková Markéta, Matyášová Alena, Jan Amos Komenský v českém a světovém výtvarném umění (1642-2016), Praha 2017.

Sanden Gottfried, von, Zur Geschichte der Lissaer Schule 1555-1905, Lissa 1905.

Smoluchowski Zdzisław, Teatry szkole w Lesznie w latach 1920-1976, „Rocznik Leszczyński" 1977, 1, s. 173-195.

Stolárova Lenka, Vlnas Vít (Ed.) Comenius 1592-1670. Doba mezi rozumem a šilenstvím. Jan Amos Komenský a jeho svět, Brno 2020.

Strobel Nicole, Johann Gottlieb Elsner - teolog reformowany pomiędzy Prusami a Wielkopolskq, w: Małus Marta, Szymańska Kamila (red.), Reformacja i tolerancja. Jedność $w$ różnorodności? Wspótistnienie różnych wyznań na ziemi wschowskiej i pograniczu wielkopolsko-śląskim, Wschowa-Leszno 2015, s. 183-198.

Szymańska Kamila, Recepcja Jana Amosa Komeńskiego w Lesznie do roku 1939 na tle zainteresowania pedagogiem i jego twórczościq w Europie Środkowej, w: B. Sitarska, R. Mnich (red.), Jan Amos Komeński a Europa XVII wieku/ Jan Amos Komenský und Europa im XVII. Jahrhunderts, „Studia Comeniana Sedlcensia”, t. IV, Siedlce 2012, wersja polsko-niemiecka, s. 53-68.

Szymańska Kamila, Użytkownicy zbiorów biblioteki i archiwum kościoła św. Jana w Lesznie w świetle dokumentów archiwalnych od XIX wieku do 1939 roku, „Biblioteka” 2019, nr 23, s. 97-120. 